\title{
Az IKT társadalmi felhasználásának perspektívái és stratégiái
}

A recenzió a Springer kiadónál 2005 nyarán ezzel a címmel megjelent angol nyelvü tanulmánykötetet (Perspectives and Policies on ICT in Society) mutatja be. A könyvet az egyik legrégebbi nemzetközi információfeldogozási szövetség, az IFIP (International Federation for Information Processing) „Számítógép és társadalom” bizottságának két tagja szerkesztette. A felkért szerzők regionális bontásban vizsgálják az információs társadalom fejlesztésével kapcsolatos stratégiákat és politikai programokat, majd a legfontosabb etikai és szociális kérdéseket veszik sorra. A tanulmánykötetben helyet kaptak továbbá az információs és kommunikációs technológiák fejlődésének hatására változó munkahelyek és az ugyancsak változó funkciójú otthon viszonyát elemző írások is.

\section{Szerzői információ:}

Kollányi Bence

Az ELTE Társadalomtudományi Karán végzett médiaszociológia szakirányon. Szakdolgozatát „Az első számítógép használata a családban: az informatikai ismeretek átadásának kalákán alapuló modellje" címmel írta. Az Információs Társadalom- és Trendkutató Intézet munkájában 2004 nyarától vesz részt, 2005 szeptemberétól junior kutatóként dolgozik. Fő érdeklődési területe az információs társadalom mérhetôvé tétele, valamint az információs társadalom kiépítésére irányu16 kormányzati stratégiák elemzése. Részt vett a Magyar Információs Társadalom Stratégiájához készült indikátorrendszer felülvizsgálatában.

\section{0}

$\mathbf{R}$

$\mathbf{M}$

Á

Így hivatkozzon erre a cikkre:

Kollányi Bence. „Az IKT társadalmi felhasználásának perspektívái és stratégiái”.

Információs Társadalom V, 4. szám (2005): 139-148.

$\Longrightarrow$ https://dx.doi.org/10.22503/inftars.V.2005.4.11


Kollányi Bence

\section{Az IKT társadalmi felhasználásának perspektívái és stratégiái}

Perspectives and Policies on ICT in Society - An IFIP TC9 (Computers and Society) Handbook. Series: IFIP International Federation for Information Processing, Vol. 179. Berleur, Jacques - Avgerou, Chrisanthi (eds.) 2005, VIII, 290 p.

A Springer Kiadó gondozásában megjelent tanulmánykötet az információs társadalom diskurzusának legfontosabb csomópontjait érintve mutatja be a fejlett és a fejlődó világ informatikai programjait. A 2005 nyarán megjelent könyv a kiadó és az egyik legrégebbi nemzetközi információfeldolgozási szövetség, az IFIP (International Federa- tion of Information Processing) ${ }^{1}$ együttmúködésében készülő sorozat 179. kötete. A közremúködő szerzók többsége a szervezet „Számitógép és társadalom” bizottságának (TC9) tagja, a tanulmányok az itt zajló munka bemutatása mellett az elmúlt két évtizedben az információs és kommunikációs technológiák (IKT) elterjedésének érdekében megtett politikai lépéseket ismertetik és értékelik. A kiadványt szerkesztóként a $T C 9$ elnöke, Chrisanthi Avgerou és a bizottság vezetésében szintén aktívan közremúködő Jacques Berleur jegyzi.

A tanulmánykötet két, közel azonos terjedelmú részból épül fel. Az elsố 100-120 oldal az információs társadalommal kapcsolatos stratégiákat és politikai programokat veszi sorra, Kínától az USA-n át Európáig bemutatva az ilyen irányú törekvéseket és egyfajta regionális áttekintést adva a témáról. Az utolsó fejezetek azonban már átvezetnek a második tematikus blokkba, és elókészítik az információs társadalommal kapcsolatos eltérố megközelítések és diskurzusok seregszemléjét.

A tanulmánykötet bevezetốjében a szerkesztốpáros hangsúlyozza, hogy a közremúködő szerzók kezét nem kötötték meg formai elóírásokkal, egységes szerkezeti elvárásokkal. Ez bizonyos esetekben a könyv elônyére is válik. Késóbb azonban azt is láthatjuk, hogy több szerző csak nagyon felszínesen közelít témájához, és mindez részben a tanulmányok eltérố múfajából adódik.

\section{Első rész}

A tanulmánykötet első fele az IKT-stratégiák nemzetközi áttekintését adja, kiemelt figyelmet szentelve a fejlődố világ információs társadalmainak. Az IFIP technikai bizottságában nem ez az első ilyen jellegú kísérlet - már 1981-ben tanulmánykötetet

${ }^{1}$ A szervezetet 1960-ban Párizsban alapították meg az UNESCO égisze alatt. Az IFIP esernyő́szervezetként múk ödik, maga alá gyưjtve a nemzeti információfeldolgozással foglalkozó szervezeteket és szövetségeket. Tevékenységének két fố területe a tagországok információfeldolgozásának támogatása, valamint a tudás- és technológiatranszfer biztosítása a fejlő́dố országok irányába. Nem profitorientált szervezet, múködését csaknem 2500 önkéntes biztosítja. A munkacsoportoknak több magyar szakember is aktív tagja, illetve vezetốje. A szervezet 14 nagyobb technológia bizottságra (technical comittee, TC) tagolódik. 
adtak ki Számitógépek a fejlódó országokban címmel, s azóta többször is visszatértek a témához. (1990: Information Technology in Developing Countries. 1998: Implementation and evaluation of information systems in developing countries.)

\section{A fejlődő országok}

A kötet az afrikai kontinens IK'T-fejlettségét bemutató írással kezdődik. Ez akár szimbolikus gesztusnak is tekinthetô, mivel a figyelmet az IKT kérdéseivel foglalkozó irodalom által kevésbé elemzett földrajzi régióra irányítja rá a figyelmet.

A tanulmánykötet egyik nagy elốnye, hogy az egyes régiók ismertetésére olyan szerzóket kértek fel, akik jól ismerik az adott terület problémáit, így a megszületố írások is hitelesek lettek. Afrika esetében például a tanulmány szerzóje egy dél-afrikai tanácsadó vállalat munkatársa. Jonathan Miller korábban a Világbank felkérésére az IKT-beruházásokat tanulmányozta Kelet-Afrikában, és az IKT elterjedését vizsgálta a kilenc demokratikus afrikai állam fejlesztési programjait összehangoló együttmúködés keretében, a Dél-Afrikai Fejlesztési Közösség (Southern African Development Community, SADC) területén. Miller a Trigrammic nevú tanácsadó cég egyik alapító tagja.

A kontinens IKT-politikájának bemutatását a szerzố a digitális megosztottság irodalmának tágabb kontextusában helyezi el. A fó törésvonalat a szegénység, az alacsony szintû́ városiasodottság és az alapvetố távközlési infrastruktúra hiánya jelöli ki. Miller értékelése szerint azonban az afrikai kontinensen nem egyszerúen csak a modern gazdasági környezet vagy az e-kereskedelem hiányzik, hanem az alapvetô távközlési infrastruktúra is.

Korábbi elemzó munkáihoz kapcsolódva Miller elôször bemutatja néhány afrikai államnak az információs és kommunikációs technológia fejlesztésére vonatkozó politikáját. A tanulmányt olvasva megtudhatjuk, hogy Mozambik, Tanzánia vagy Ruanda IKT-politikái, amelyek az ezredforduló óta vannak érvényben, milyen vezérelvek és fontosabb szempontok mentén épülnek fel. Mindez azonban csak ízelítóül szolgál, a mélyebb összefüggések megértésére a tanulmány terjedelme nem ad lehetôséget. A továbbiakban Miller a digitális megosztottság egyik avatott szakértôje, Mark Warschauer által megjelölt négy kulcsterületre összpontosítva fejti ki a speciális afrikai szempontokat $^{2}$ a First Monday címú online folyóiratban publikált tanulmányban.

A kínai IKT-használatról a Capinfo (Capital Information Development Company) elnök-vezérigazgatója, X. Chen és további két munkatársa, J. Gao és W. Tan közölt áttekintő elemzést. A szerzók ismét csak közel vannak a túzhöz: ez az 1998-ban alapított, sikeres kínai számítógépes vállalat online üzleti tranzakciókat kínál, jelenleg pedig a 2008-as pekingi olimpia weblapján dolgozik. A tanulmány elsố gondolati egységében Kína sajátos helyzetét ismertetik. Értékelésük szerint Kínának egyidejúleg kell helytállni a nemzetközi versenyben és megvalósítani az ország jólétét biztosítani hivatott iparosítási programot, s eközben az információs társadalom kihívásaira is reagálnia kell.

\footnotetext{
${ }^{2}$ Mark Warschauer: Reconceptualizing The Digital Divide. First Monday, vol. 7, number 7 (July 2002). http://firstmonday.org/issues/issue7_7/warschauer/index.html
} 
Ezek a gondolatok leginkább Dessewffy Tibor kettősátmenet-elméletével mutatnak rokonságot (Dessewffy, 2002).

A kötetben szereplő kínai tanulmány szerzóinek következtése szerint Kínában a késốn jövốk elốnyét kell kihasználni: a versenyképesség megteremtése érdekében az IKT-iparág fejlesztésére van szükség. Ez a megállapítás egybecseng a kínai kommunista párt 16. kongresszusán megerôsített politikával, ami a következóket irányozza elő a következő 20 évre:

- a szocialista piacgazdaság tökéletesítése,

- az iparosítás megvalósítása,

- informatizáció,

- a modernizáció felgyorsítása.

Mindezek a változások a gazdaság fenntartható és egészséges fejlődését célozzák, ami az idézett kongresszusi állásfoglalás szerint az emberek életminőségének folyamatos javulását eredményezi.

A fejlődố országokhoz kapcsolódik még S. Sadagopan és J. Weckert tanulmányának elsố része, amely az IKT indiai elterjedését vizsgálja (a második rész - hasonló szempontok szerint - Ausztráliával foglalkozik). A szerzók kiemelik az 1980-as években hozott korai intézkedéseket, melyek révén Indiába kedvezó feltételekkel jutottak be a számítástechnikai eszközök, s így lehetôvé vált a hazai fejlesztés megkezdése. (Többek között „zéró vámot” vezettek be a szoftvertermékekre.) Az 1990-es évek második felében elért tartós, évi 50\%-os növekedése részben ezeknek a lépéseknek volt a következménye. Az összehasonlító tanulmány rövid áttekintést ad a vizsgált két országban fokozatosan végbement teljes körú piacnyitásról, bemutatva az e-gazdaság fontosabb fejlődési trendjeit. Az Ausztráliával foglalkozó részben valamilyen oknál fogva még a tartalomipar szabályozási kísérletei is megjelennek.

\section{A fejlett országok}

Az információs politikával foglalkozó írások közül kiemelkedik az Európai Unióval foglalkozó tanulmány, amelyet a kötet egyik szerkesztóje, Jacques Berleur egyetemi kollégájával, Jean-Marc Galanddal közösen jegyez. A szerzók az Unió IKT-politikáját elemezve két szakaszt különítenek el: az 199, és 1999 közötti öt év a Bangemann-jelentés jegyében telt el, míg az 1999-et követố idốszakot az újonnan létrehozott Információs Társadalom Fóigazgatóság által elốterjesztett $e E u r o p e$ akciótervek fémjelzik.

199, júniusa, Korfu - az Európai Bizottság csúcstalálkozóján elfogadják az úgynevezett Bangemann-jelentést. Berleur és szerzótársa szerint ezzel vette kezdetét az EU IKT-politikájának első, jól körülírható fejezete, amely 1999-ben az eEurope akcióterv elfogadásával zárult. A napjainkig tartó második szakasz kezdetét a szociáldemokrata Erkki Liikanen vezette új Információs Társadalom Főigazgatóság és a Bizottság elnöke, Romano Prodi által életre hívott eEurope programok beindítása jelentette.

A szerzópáros módszeresen mutatja be a legfontosabb intézkedéseket és az elfogadott stratégiai dokumentumokat. Érzékelteti az elsố kísérletek és az eEurope 2005 kö- 
zött lezajlott fejlôdést. Ugyanakkor - anélkül, hogy a programok jelentôségét elvitatná - meglehetôsen kritikusan viszonyul azokhoz.

A tanulmány két szempontból is támadja az EU akcióterveit. Elsóként a programok értékelésének gyengeségeire hívja fel a figyelmet. Az eEurope programok elörehaladásának mérésére szolgáló indikátorok a szerzók szerint nem állnak összhangban a programban megfogalmazott célokkal, egy stratégia eredményeinek elemzése azonban nem képzelhetố el a lefektetett célok és a hozzájuk rendelt mutatók kölcsönös megfeleltetése nélkül. A tanulmány példaként említi az internetet rendszeresen használó egyénekre vonatkozó mutatót, amely nem köthetố közvetlenül az eE urope egyik megfogalmazott céljához sem. A stratégiákhoz rendelt indikátorok sok esetben a könnyen mérhetô mutatókból indulnak ki, s így a kívánt összhang csak jelentős többletráfordítással és módszertani munkával válna elérhetôvé.

A másik izgalmas kritikai észrevétel az eEurope akciótervek társadalmi legitimitására vonatkozik. Mára elmondhatjuk, hogy az információs társadalom kiépítésére vonatkozó politika kidolgozása Európában megtörtént, elsősorban az eEurope stratégiák formájában. Ugyanakkor hiányzik az a társadalmi igazolás, ami az európai polgárok többségének életére már középtávon is hatással lévố program széles körü támogatását jelentené.

A tanulmány szerzôi felteszik továbbá azt a kérdést is, hogy a piac nem lenne-e képes autonóm módon, önszabályozó formában elérni az IKT-eszközök széles körú társadalmi elfogadását és alkalmazását. Miért van szükség az EU közbelépésére? A beavatkozások kapcsán a demokratikus kontrollt hiányolják: véleményük szerint az információs társadalom kiépítésére vonatkozó intézkedések is éppen olyan mértékben (esetleg épp olyan kevéssé) demokratikusak, mint az EU összes többi döntéshozatali eljárása.

Az egyes régiók és országok IKT-politikáját bemutató tanulmányokat $Z$. Karvalics Lászlónak, az Információs Társadalom- és Trendkutató Központ kutatási igazgatójának a tollából származó írás követi. Ez az információs társadalmak kialakulását és globális versenyét történelmi távlatba helyezô tanulmány egyben le is zárja a kötet elsố részét.

$\mathrm{Az}$ információs társadalom fejlődésének 20. századi történetét Karvalics a korai magaskultúrák kommunikációs hálózatának ismertetésével alapozza meg. Az egykori római birodalom vagy az egyiptomi fáraók által üzemeltetett postarendszer, a Fai Sát bemutatása már ismerốs lehet a magyar olvasóknak. ${ }^{3}$ A tanulmány szerzóje az információs társadalom kialakulását ezúttal elsősorban versenyproblémaként értelmezi. Két korszak eseményeit ismerteti: elsóként az 1956 és 1978 közötti fejlődési idószakot tekinti át, amely az amerikai-japán tandem versenyével jellemezhetố, majd az 1991-ig tartó bó tíz évet vizsgálva az új versenytársak - vagy ahogy korábbi múveiben ${ }^{4}$ frappánsan nevezte, az üldözóboly - megjelenését elemzi.

Karvalics magát információtörténésznek vallja, szenvedélyes gyưjtője az információ előállításához, sokszorosításához, terjesztéséhez kapcsolódó történeti forrásoknak. A kötetben szereplő tanulmányában is felhasznált egy ilyen leletet: A „Rádióamatốr” címú újság egyik 1929. évi száma a rádió-átjátszóállomások elterjedtségéról közölt nem-

${ }^{3}$ A 2000-ben megjelent Fogpiszkáló a hálózaton címû gyưjteményes kötetében több írás is foglalkozik a témával.

${ }^{4}$ Z. Karvalics László (2002): Az információs társadalom keresése. Budapest: Aula Kiadó. 
zetközi adatokat. A listát az Egyesült Államok vezette 6,,8 adóval, majd jóval lemaradva, száznál kevesebb toronnyal Svédország, Németország, Anglia és vele holtversenyben Ausztrália következett. Karvalics ezt a kezdetleges „országrangsort” vetette össze az International Data Corporation (IDC) több mint 70 évvel késóbb készített listájával, amely az országok felkészültségét értékelte. Az IDC természetesen lényegesen bonyolultabb elemzési szempontok alapján rangsorol, mégis feltúnő, hogy a mostani elsô 20 helyezett hasonló eredménnyel szerepelt a korábbi összesítésben is: az 1929. évi listából csak Szingapúr, Tajvan és Izrael hiányzott.

A determinisztikusnak túnố párhuzam ellenére Karvalics mégis azt érzékelteti, hogy az információs társadalom fejlesztésére irányuló, megfelelóen kidolgozott stratégiával a ma még lemaradók között számon tartott országok is felemelkedhetnek. Sôt, ez az egyetlen igazi esélyük.

\section{Második rész}

A szerkesztók az információs társadalom diskurzusának fontosabb csomópontjai mentén válogatták össze a kötet második felében szereplő tanulmányokat. Az IFIP TC9 tevékenysége nagyobb témakörre terjed ki, mint amit a tanulmányok átfognak, de a társadalom és a számítástechnika viszonyának talán legfontosabb dimenziói megjelennek a kötetben. Az IFIP felépítéséról még érdemes elmondani, hogy az egyes technikai bizottságok alá úgynevezett munkacsoportok (Workgroups, WG) tartoznak. A kilencedik bizottság (TC9) összesen kilenc ilyen munkacsoportból áll össze.

WG 9.1: A számítógépek és a munka (Computers and Work)

WG 9.2: 'Társadalmi felelôsség, elszámoltathatóság (Social Accountability)

WG 9.3: Otthoni használatra szánt informatikai és telematikai eszközök (Home Oriented Informatics and Telematics)

WG 9.4: A számítógépek társadalmi hatásai a fejlődô országokban (Social Implications of Computers in Developing Countries)

WG 9.5: A virtuális világok alkalmazásai és társadalmi következményei (Applications and Social Implications of Virtual Worlds)

WG 9.6: Az információs technológia helytelen felhasználásai; visszaélések és a jog (Information Technology: Misuse and The Law) (A 11.7 munkacsoporttal közösen vizsgált témakör)

WG 9.7: A számítástechnika története (History of Computing) nology)

WG 9.8: A nók és az információs technológia (Women and Information Tech-

WG 9.9: Az IKT és a fenntartható fejlődés (ICT and Sustainable Development)

A tanulmánykötetben helyet kapott írások három kiemelt területhez köthetốk. Az alábbi témakörök magukban foglalják a fentebb ismertetett munkacsoportok tevékenységeinek több mint a felét: 
- a munkahely és az otthon viszonyának átalakulása a számítógépek korában,

- digitális megosztottság,

- etikai kérdések, privacy.

A három kiemelt területen kívül néhány más témakör is megjelenik a kötetben. Több tanulmány foglalkozik az oktatás változásával az információ korában, és az írások között akad olyan is, amely a fogyatékosok számára kifejlesztett informatikai eszközökkel foglalkozik.

\section{A munkahely és az otthon viszonyának átalakulása}

Peter Mambrey az IFIP 9.1. munkacsoportjának kutatásairól ír. Mambrey a TC9 elnökségének tagja, a németországi Alkalmazott Információs Technológiai Intézet (Fraunhofer Institute for Applied Information Technology, FIT) munkatársaként a számítógéppel támogatott együttmúködés adaptálhatóságát tanulmányozza különféle munkakörnyezetekben. A tanulmánykötetben szereplố írásában az 1970-es évek végétôl napjainkig elemzi a munka és számítógép viszonyával foglalkozó diskurzus fôsodrát.

A kezdeti szakaszban a számítógép-használat közösségi hatásai egy jól meghatározható intézményhez, a térben és idóben egyaránt elkülönülő munkahelyhez voltak köthetók. Két évtizeddel késóbb, az 1990-es évek végén azonban már számos országban megjelentek a távmunkával kapcsolatos elemzések is. Ennek ellenére az irodalom eleinte szinte egyáltalán nem foglalkozott a hálózatosodó kapcsolatrendszerekkel. A munkavégzéssel kapcsolatos megközelítések alakulását, fejlődését olyan új hívó szavak megjelenése jelezte, mint a virtuális munka, a hálósati munka vagy a virtuális szervezet.

A tanulmány zárásaként Mambrey egy gyakorlati kérdést ajánl továbbgondolásra: Az információs és kommunikációs technológiák terjedésével vajon több lehetôség - vagyis munkahely - jön-e létre, vagy az automatizáció, a munkafolyamatok hatékonyságának növelése és a bizonyos munkafázisok kiküszöbölésével megszúnô munkahelyek a negatív irányba billentik el a mérleget? A szerzố szerint ez a gondolatmenet egyértelmúen az életminőség és a számítógépek kapcsolatának újragondolásához vezet.

Ebben a témakörben még izgalmasabb a Wolverhamptoni Egyetem kutatója, Andy Sloane tollából származó írás. A szerzô elsốsorban az otthon változó szerepét vizsgálja, bemutatva az információs technológiák hatásait. Az ipari társadalmak fontos alappilléreit alkották a munkafolyamatok ellenőrzését biztosító üzemek és hivatalok, illetve a polgárosodó otthonok, amelyek élesen elválasztották egymástól a munkát és a magánéletet. Az információs társadalom - a szerző gondolatmenete szerint - az otthon és a munkahely viszonyának radikális átalakulását hozza magával. Ezt a folyamatot jól érzékelteti az atipikus munkavégzési formák megjelenése, különös tekintettel az otthon végzett távmunka elterjedésére.

A tanulmány nagymértékben támaszkodik az otthoni használatra szánt informatikai és a telematikai eszközökkel foglalkozó 9.3 munkacsoport elemzéseire. Az otthonhoz kapcsolódó interakciókat és tevékenységeket vizsgálja, bemutatva azokat a min- 
dennapi életben bekövetkezó változásokat, amelyek az IKT-használattal függnek össze. Az információs technológia társadalmi hatásai közül négy dimenziót emel ki, ezeket azonban csak meglehetôsen felületesen tekinti át. A befoglalás és a kirekesztés dimenziójában a folyamatosan csökkenó költségeket állítja szembe az IKT-eszközök magas árával, ami hozzájárul egyes társadalmi csoportok lemaradásához. Az integráció és az izoláció ellentétpárjával szintén két egymásnak feszülő folyamatot ír le, melyeknek a pozitív oldalát a technológia személytelensége biztosítja: e sokszor hangoztatott vélemény szerint a technológia nem tesz különbséget az emberek között származás, nem és kor alapján, pontosabban képes ezeket a különbségeket elfedni. A harmadik elemzési szempont a mobilitás, amelynek alapját a vezeték nélküli hálózatok növekvố sávszélessége és a harmadik generációs telefonok alkotják. A mobilitás fokozódásával megjelenik a „Legyen mindig, mindenïtt online!” jelszavát követő ember víziója is. A negyedik fontos elemként Sloane a választási lehetóségeket emeli ki: az információs korban az internet segítségével hozzáférhetô információk és szolgáltatások mindenkinek megadják a választás szabadságát. Ezt követốen még felveti a választás csökkenésének lehetőségét is, példaként említve azokat a rendszereket, ahol a felhasználó rendelkezésére álló szoftver és a hardver nem biztosít alternatívákat. Zárásként - visszatérve eredeti témájához - annak a valószínúségét hangsúlyozza, hogy az információs társadalom további kiteljesedése során az otthon központi szerepe tovább fog erôsödni, miközben funkciói megváltoznak és kibôvülnek.

\section{Etika}

Az információs technológia fejlődése hatással van mindennapi életünkre. Ez előnyöket és hátrányokat is jelent: Penny Duquenoy tanulmányában - Sara Baase munkái nyomán - az egyénekre gyakorolt pozití és negatí hatások arányának alapján határozza meg a számítástechnikával kapcsolatos etikai kérdéseket. Duquenoy a számítógéphez kapcsolódó etikai diskurzus gyökereit az 1950-es évek közepéig vezeti vissza, ekkor fogalmazta meg ugyanis Norbert Wiener a gépek fejlődésével kapcsolatos aggályait, abból kiindulva, hogy a komplex folyamatok irányítása során a gépek gyorsabban reagálnak, mint ahogyan az emberek képesek lennének érdemi döntéseket hozni és cselekedni. A legfontosabb elốzményként Duquenoy - a tanulmánykötet más szerzóihez hasonlóan - Joseph Weizenbaum korai munkáit nevezi meg. Weizenbaum 1976-ban megjelent könyvében ${ }^{5}$ a mesterséges intelligenciával kapcsolatos etikai kétségeinek adott hangot. Az MIT kutatója tíz évvel korábban egy meglehetôsen egyszerú program kidolgozásával írta be a nevét a számítógépek és az ember viszonyát vizsgáló, kísérleti szociálpszichológiai alapokra építô vizsgálatok történetébe. Az ELIZA nevú program elốre programozott válaszok alapján, egyszerú nyelvi alapokon és a pszichológiától kölcsönvett panelekre építve pszichológiai kezelést szimulált. Az empatikusra hangolt számítógépes program számos önkéntest megtévesztett, a számítógép elốtt ülố alanyok ốszintén megnyíltak,

${ }^{5}$ Joseph Weizenbaum: A computerek hatalma és az emberi értelem: Döntéstól a kalkulációig. [Részletek.] Ford. Kozma Katalin. Közmúvelődési Információs Központ, 1985. (Computer power and human reason: from judgment to calculation. San Francisco: Freeman, 1976.) 
és kétségük sem volt afelól, hogy valódi pszichológussal beszélnek. Weizenbaumot sokkolták az eredmények: ezt követôen jelentette meg a mesterséges intelligencia veszélyeivel foglalkozó nagy hatású tanulmányát.

Duquenoy a korai alapok ismertetése után az internet megjelenésével felerôsödố „digitális” etikai problémákról ír. A felhasználók számának dinamikus növekedésével, a kommunikációs csatornák digitalizálásával a kéretlen elektronikus üzenetek áradata indult meg. Duquenoy hasonlóan problematikus területnek tartja az elektronikus postaforgalom és egyéb internetalapú tevékenységek megfigyelését is, ami a kialakuló új privát szféra megsértését. A felmerülő etikai kérdések sorát az azonosithatóság hiányával, az anonimitásból fakadó problémákkal és a szerzói jogok rendszeres megsértésével folytatja.

Késốbb-megint csak Weizenbaumra hivatkozva - a nyelvfelismerés veszélyeire hívja fel a figyelmet. Az információs társadalom orwelli vízióját vázolja fel: a telefonbeszélgetéseket a kormányzatok korábban csak jelentős humán erőforrások ráfordításával tudták lehallgatni, a hangalapú kommunikációt felismerő és írott szöveggé alakító programokkal és megfelelố kulcsszavak alkalmazásával azonban az ehhez szükséges erốfeszítés a töredékére csökkenthetố. Az Egyesült Államok kezdetben „Teljes körû́ információs éberség" (Total Information Awareness, TIA) néven meghirdetett, azóta takaréklángon érlelődő programja a rendelkezésre álló adatok hasonló elemzésére épített.

A konklúzió a kétségek ellenére mégis pozitív: a szerzô felhívja a figyelmet arra, hogy a számítástechnika megjelenése mindennapi életünkben számos elônnyel jár, példaként a globális kommunikáció kiteljesedését említi. A kommunikáció már a számítástechnika kifejlődését megelôzốen is behálózta a Földet, de a költségek drasztikus zuhanását valóban az internet-protokollok használatának elterjedése hozta meg. A tanulmányt Duquenoy Norbert Wiener szavaival zárja: „Képzeletünk minden erejével azon kell fáradoznunk, hogy megvizsgáljuk, az új modalitások alkalmazása merre vezet bennünket."

Az internet felügyeletének kérdése először 1998 októberében vált igazán közérdekú témává, ugyanis az internetprotokoll-azonosító számok és a domainnevek kiosztásának szabályozása ekkor került az ICANN (Internet Corporation for Assigned Names and Numbers) elnevezésú nonprofit szervezethez. Ezt megelő́zően az Egyesült Államok kormánya és az IANA (Internet Assigned Numbers Authority) nevú állami szervezet felelt ezért - írja tanulmányában a kötetet társszerkesztốként is jegyzố Jacques Berleur. Az internet irányításával foglalkozó és szintén etikai megközelítéssel éló írás legfontosabb állítása, hogy a folyamatokat továbbra is az önszabályozás irányában kell alakítani.

Berleur többek között a következô - elsősorban az önszabályozást propagáló ajánlásokat fogalmazza meg tanulmányában:

- Különleges figyelmet kell fordítani a hozzáféréssel kapcsolatos egyenlő jogokra, különös tekintettel az egyetemleges hozzáférésre.

- Részvétel az önszabályozó kódok megalkotásában.

- Kérdezzük meg magunktól: a jelenlegi önszabályozás nem elsősorban a piac védelmét, az új szereplók belépésének korlátozását célozza?

- Az önszabályozás jelenjen meg a jogszabályokban! 


\section{Digitális megosztottság}

Az információs társadalom diskurzusa Európában és az USA-ban már az 1990-es évek elején tárgyává tette a digitális megosztottság problémáját és a szegényebb országok fejlődésének kérdéseit. C. Avgerou, a London School of Economics and Political Science ( $L S E$ ) gazdasági kutatóintézet információs rendszerekkel foglalkozó osztályán dolgozó professzor a fejlődő országok avatott szakértôjeként elismert munkatársával, S. Madonnal közösen jegyezte a tanulmánykötet egyik igen érdekes írását, amely a digitális megosztottságot elemzó irodalom fejlődésének irányát bírálja.

A tanulmány három alfejezetból épül fel. Az elsố rész az információs társadalom diskurzusának változását mutatja be, a fejlődố országok számbavételével. Ezt követốn a szerzók a a szegény országok szocioökonómiai dimenziói mentén gondolják tovább a digitális megosztottság problémáit és elemzik azokat. A harmadik részben megoldást javasolnak a digitális megosztottság tekintetében többnyire csak szúken értelmezett techno-gazdasági megközelítést alkalmazó diskurzus kibôvítésére. Lényegében azt javasolják, hogy a fejlődố országok esetében felejtkezzünk el a hagyományos IKT diskurzusról, és olyan eljárást válasszunk, amely képes fényt deríteni az egyedi jelenségekre is, és ahol az adott körülmények folytán az információforrások épp olyan jelentőséggel bírnak, mint maga a technológia, hasonló súllyal veszi figyelembe az egyes országok történetileg kialakult jellegzetességeit.

Az információs technológiákat és a távközlési rendszereket már a kezdetektól fogva példátlanul hatékony eszközöknek tekintették a fejlődő világ felzárkózásához. A mikroszámítógépek és az oktatási szoftverek alkalmazásától azt várták, hogy a diákokat - a sokszor képzetlen tanárok munkáját segítve - közelebb hozzák a tudományos és technológiai pályákhoz, és megteremtik a modern üzletvitel alapjait. Hasonló reményekkel tekintettek az e-kormányzásra, az e-gazdaságra, melynek segítségével a perifériák is bevonhatók a világkereskedelembe, valamint a fejlődő országok egészségügyi problémáit enyhítố távgyógyászatra is. Ez a bizakodás nagyon hamar különféle konferenciákon kezdeményezett nemzetközi együttmúködési és támogatási programok formájában is megjelent (Dotforce, WSIS, WITFOR). ${ }^{6}$

A szerzók felhívják a figyelmet arra, hogy az információs társadalom kiépítésének lehetôségét felkínáló politikai programok a fejlődő országok számára rendszerint egyirányú tudásáramlással jártak együtt. A fejlett országok implicit formában, egyfajta knowhow gyanánt adták át kimondatlan tudásukat, felülírva a fejlődés irányát, ez azonban a helyi körülmények figyelembevétele nélkül gyakran semmit sem ér. Afrikában például az „információs társadalom” megvalósítása - néhány pozitív példától eltekintve - csupán a távközlési infrastruktúra kiépítésére korlátozódik.

A digitális megosztottság problémáit a tanulmány - Pippa Norris nyomán - a következő három tengely mentén tekinti át:

- a fejlett ipari országokat a fejlődő országoktól elválasztó globális megosætottság,

${ }^{6}$ Dotforce: Digital Opportunity Task Force (a G8 országok ezzel a témakörrel foglalkozó szervezete). WSIS: World Summit on the Information Society. WITFOR: World Information Technology Forum. 
- az információgazdagok és az információszegények között fennálló társadalmi megosztottság,

- az online közösségen belül a közéletben aktívan résztvevóket a passzív felhasználóktól megkülönböztető demokratikus megosztottság.

Tanulmányukban Avgerou és Madon - a Kirkman és munkatársai által végzett kutatásokra hivatkozva - felhívják még egy érdekességre a figyelmet a fejlődô országokkal kapcsolatban. India esetét vizsgálva rámutatnak, hogy itt a hálózati gazdaságra és a hálózati kultúrára nyitott rétegek együtt élnek a társadalom hátrányos helyzetben lévő, óriási lélekszámú csoportjaival, amelyek teljes mértékben el vannak vágva a hálózati világtól.

\section{Kinek ajánljuk?}

A tanulmánykötet egyik legnagyobb erôssége, hogy ötvözi az információs társadalommal kapcsolatos társadalomtudományi és politikai diskurzust. A szerkesztók igyekeztek minél több különbözó földrajzi térségból válogatni a közölt írásokat. Ennek ellenére (vagy éppen ezért) a tanulmányok nehezen hasonlíthatók össze, többségük inkább csak érdekességeket emel ki és nem az adott ország IKT-politikájának bemutatására törekszik. Ezek az írások számos érdekes adalékkal szolgálnak a téma iránt érdeklődő társadalomtudósoknak, de politikusok és az üzleti élet képviselối is profitálhatnak belólük. A második rész kimondottan a komplex problémaérzékenységet fejlesztő, olykor bevezető jellegú írásokat tartalmaz, így elsôsorban mérnököknek, számítástechnikai szakembereknek, valamint az információs társadalommal foglalkozó politikusoknak és más döntéshozóknak ajánlható. 